\title{
Contested Organizational Change and Accounting in Trials of Incompatibility
}

\author{
Christensen, Mark; Skærbæk, Peter; Tryggestad, Kjell
}

\author{
Document Version \\ Accepted author manuscript \\ Published in: \\ Management Accounting Research
}

DOI:

10.1016/j.mar.2019.03.001

Publication date:

2019

License

CC BY-NC-ND

Citation for published version (APA):

Christensen, M., Skærbæk, P., \& Tryggestad, K. (2019). Contested Organizational Change and Accounting in Trials of Incompatibility. Management Accounting Research, 45, [100641].

https://doi.org/10.1016/j.mar.2019.03.001

Link to publication in CBS Research Portal

\section{General rights}

Copyright and moral rights for the publications made accessible in the public portal are retained by the authors and/or other copyright owners and it is a condition of accessing publications that users recognise and abide by the legal requirements associated with these rights.

\section{Take down policy}

If you believe that this document breaches copyright please contact us (research.lib@cbs.dk) providing details, and we will remove access to the work immediately and investigate your claim.

Download date: 26. Apr. 2023

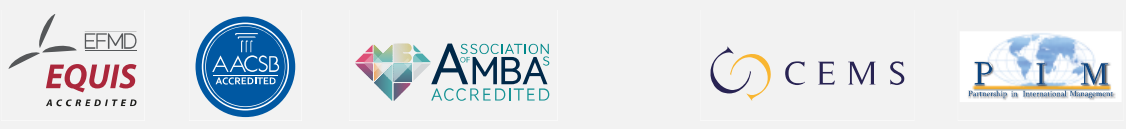




\section{Contested Organizational Change and Accounting in Trials of Incompatibility}

\section{Mark Christensen, Peter Skærbæk, and Kjell Tryggestad}

Journal article (Accepted manuscript*)

\section{Please cite this article as:}

Christensen, M., Skærbæk, P., \& Tryggestad, K. (2019). Contested Organizational Change and Accounting in Trials of Incompatibility. Management Accounting Research, 45, [100641].

https://doi.org/10.1016/j.mar.2019.03.001

DOI: https://doi.org/10.1016/j.mar.2019.03.001

* This version of the article has been accepted for publication and undergone full peer review but has not been through the copyediting, typesetting, pagination and proofreading process, which may lead to differences between this version and the publisher's final version AKA Version of Record.

Uploaded to CBS Research Portal: August २०२०

(C) २०19. This manuscript version is made available under the CC-BY-NC-ND 4.0 license http://creativecommons.org/licenses/by-nc-nd/4.0/ 
Contested organizational change and accounting in trials of incompatibility

Mark Christensen, Kjell Tryggestad and Peter Skærbæk

Work-in-progress 


\begin{abstract}
This paper is about the role of accounting in making decisions about contested organizational change. We study how two strategic options emerged and were valued differently in a protracted case regarding sourcing by the Danish Defence Force. Drawing on Actor-Network Theory we show how the two strategic options emerged and were pitted against each other in what Callon describes as 'trials of strength'. The contribution of the paper is in three actions: First, it develops the concept of 'trial of strength' for accounting and organizational research by showing that extant literature can be enhanced with the conceptualization of a typology of trials that distinguishes between prototype trials and trials of incompatibility. Second, it shows that accounting inscriptions may play changing roles which we label 'versatile' when forged in the contested circumstances and resultant pressure of a trial of incompatibility. Third, it highlights how accounting inscriptions take part in (re)formulating, evaluating and advancing mutually exclusive reform options in a series of trials of strength involving both a prototype trial and trials of incompatibility. In addition to the frequency, number and intensity of the inscriptions there appears to be an increased prospect of unfaithful behavior by some inscriptions. This work also has implications for governmentality theorization and processual views of outsourcing decision making - as well as its paradoxical outcomes.
\end{abstract}




\section{Introduction}

The relationships between accounting inscriptions and organizational change are of central interest to accounting scholars (Christner and Strömsten, 2015; Jeacle, 2017; Miller and O'Leary, 2007; Revellino and Mouritsen, 2015; Robson, 1992; Robson, Humphrey, Khalifa and Jones, 2007; Rowe, Shields and Birnberg, 2012).

With respect to an organizational change proposal, we trace events with particular attention to moments of direct confrontation of claims: trials of strength (Boltanski and Chiapello, 2005; Callon, 1986, 2007; Latour, 1987, 1988) defined as struggles between opposing forces. Within the accounting literature, some authors have invoked the concept of trials of strength (Briers and Chua, 2001; Revellino and Mouritsen, 2009). Their research shows interesting instances of what we label 'prototype' trials of strength in that they relate to the implementation of a strategic option that has developed into a testable first example, like that of an accounting technology or system prior to cutover into production. Their studies show how a prototype becomes exposed to a stream of trials. Dwelling in this field, we examine a case of decision making concerning public sector outsourcing in which two imagined futures of the organization presented themselves. In addressing this case, we supplement these earlier actor-network-theory based contributions by considering the distinction between prototype trials and trials of incompatibility, i.e., a change involving incompatible options where only one option will prevail. Our purpose is twofold; first, to better understand how accounting is implicated in shaping and valuing organizational change options before implementation of a prototype change. Second, and relatedly, to better understand the emergence of 'trials of incompatibility', notably how a prototype trial transforms and becomes a trial of incompatibility and in which we focus on the roles of accounting. 
Within the accounting change literature, scholars have used the concept of mediating instrument, i.e., that accounting inscriptions may perform to the purpose of their issuer (Christner and Strömsten, 2015; Jordan, Mitterhofer and Jørgensen, 2013; Miller and O’Leary, 2007). However, as Justesen and Mouritsen (2011) point out, actor-network-theory based research and has mostly been applied within the context of accounting change. Foucauldian inspired governmental research on the other hand has paid much attention to how accounting is enabling (smoothly) organizational change. Less attention has been given to conflicting accounting calculations in organizational change. We respond to the call by Christner and Strömsten (2015) for research of conflicting accounting calculations in organizational development trajectories.

In taking up this challenge, we emphasize how, in trials of incompatibility, mutually exclusive options develop before they eventually are terminated or allowed to become implemented. Such developments, as Latour (1988, p. 148) argues, imply that faithful accounting inscriptions work to achieve a well-aligned array of alliances with actors such that change will occur: "Faithful translators or unfaithful traducers? Nothing is known, only realized through a trial of strength". Latour's argument seems to imply that the accounting researcher should be careful to avoid an attribution error in assuming a faithful or strong role for accounting: and instead direct attention to how accounting can play more shifting and unexpected roles.

In taking up this challenge, we emphasize how, in trials of incompatibility, mutually exclusive options develop before they eventually are terminated or allowed to become implemented. In such trials whether accounting inscriptions are faithful or unfaithful is of interest: "Faithful translators or unfaithful traducers? Nothing is known, only realized through a trial of strength" (Latour, 1988, p. 201). Latour's argument puts accounting researchers on notice that they should be careful to avoid 
an attribution error in assuming a faithful or strong role for accounting; instead direct attention to how accounting can play more shifting and unexpected roles is needed since:

"We always misunderstand the strength of the strong. Though people attribute it to the purity of an actant, it is invariably due to a tiered array of weaknesses." (Latour, 1988, p. 201).

We therefore direct attention to how accounting can play a shifting and unexpected role during a sequence of prototype- and incompatibility trials, what we call the versatile role for accounting. By 'versatile role' we mean the ability of accounting inscriptions, upon release into circulation, to alter from conveying one message to the conveyance of a totally different message, or effect. Accounting inscriptions can variously possess that ability without their creators necessarily being able to anticipate the interpretation and effect of that message after the inscriptions have been released. We also commence our study with the consideration that altered meanings between actors may emerge and that frequently produced and consumed accounting inscriptions may cause surprises and deflections in the course of the trials. Like a growing body of accounting researchers, we invoke Actor-Network-Theory (ANT) to assist our study of the case. However, it appears that little research has been conducted from the perspective of the "tiered array of weaknesses" (Latour, 1988, p. 201), and in particular those regarding trials of incompatibility.

We rely on a 6-year case study in the Danish Defence Force (in Danish: Forsvaret; hereafter 'DDF') featuring contested organizational change. In our case, the DDF were grappling with a response to pressures to comply with a specific reform that had spread over many countries: outsourcing of military facilities services. That imagined future was not welcomed by large parts of the DDF and they began to imagine a mutually exclusive future in which facilities services would not be outsourced but their internal provision would be made more efficient, flexible and multiskilled workforce - 'internally optimized', in their words. Implementation of outsourcing 
organizational change would result in a large part of the DDF's workforce being employed outside the DDF. The identity of the work force as well as the facility management (FBE) unit was at stake since 900 people would either be transferred to a private company, made redundant or change job tasks. In this case we trace two significant trials, ones where some accounting inscriptions produced by either side of the trial did not behave faithfully to the purpose of the proponent who produced them. These accounting actions are integral to our concept of 'trials of incompatibility' and in each trial some participants were extremely surprised and disappointed by the resultant decision, that is, the outcome of the trial, because it rendered their strategic option in a weaker position.

The contributions provided by this article are three. First, it develops the concept of 'trial of strength' for accounting and organizational research by showing that extant literature can be enhanced with the conceptualization of a typology of trials that distinguishes between prototype trials and trials of incompatibility. Second, it shows that accounting inscriptions may play changing roles when forged in the contested circumstances and resultant pressure of a trial of incompatibility. Third, it highlights how accounting inscriptions take part in (re)formulating, evaluating and advancing mutually exclusive reform options in a series of trials of strength involving both a prototype trial and trials of incompatibility.

The remainder of the article is structured as follows. In the next section, literatures of relevance are described broadly around the concept of trial in accounting and organizational change literature and how accounting inscriptions have been theorized. After discussing these literatures, the article accounts for its method and data sources before presenting the case narrative. The case and analysis are then followed by a section which discusses and concludes on the contributions. 


\section{Organizational change, Actor-Network-Theory and trials of strength}

Accounting research has provided several rich case studies of the development and implementation of accounting technologies to shape practices and identities of citizens and organizational members (refer for example: Briers and Chua, 2001; Jeacle, 2003, 2017; Miller and O'Leary, 2002; Preston, Cooper and Coombs, 1992; Revellino and Mouritsen, 2015; Skærbæk, 2009). The literature on the role of accounting has been growing ever since the seminal paper by Burchell, Clubb, Hopwood, Hughes and Nahapiet (1980), where they developed the now well-known roles of accounting as: an answer machine in situations where there are no ambiguities regarding goals; as an ammunition machine, when there is ambiguity regards goals; as a learning machine, where there is ambiguity regarding methods (means); and, an ex-post rationalization machine when there is ambiguity regarding goals and methods (means).

Burchell et al. (1980) took inspiration from Thompson and Tuden's contingency approach. Thus, Burchell et al. (1980) argued that accounting can play several roles in contentious decision-making situations. For example, their notion of an 'ammunition machine' has been used by several scholars to convey understandings of accounting to support and sustain self-interest (Rowe, Shields and Birnberg 2012). Chenhall, Hall and Smith (2014) suggest accounting has a role in expressing values and in shaping organizational identities. Some ANT-inspired accounting research considers the development and implementation of accounting systems, i.e. focus on accounting change (Preston et al., 1992; Briers and Chua, 2001; Lowe, 2000). For example, Preston et al. (1992) provides a study on how a prototype of management budgeting was tested in a 'trial hospital' (p. 586). Relatedly, and prior to the above ANT inspired contributions, Earl (1978) argued for the usefulness of a trial "prototype procedure" to develop and innovate accounting systems. In summary, these contributions are examples of what we term 'prototype trials', focusing on particular instances of 
accounting change and involving an imagined future that is compared to the present. The prototype trial is used to make a decision as to either progress the prototype (or a variant) towards the desirable future state it inscribes or abort the prototype and resume to the status quo.

Although it may be loosely coupled to the initial goals, accounting frequently seems to be strongly connected to strategic organizational change. In the accounting literature, there has been some emphasis on accounting as a mediating instrument (Christner and Strömsten, 2015; Jordan et al., 2013) that faithfully implements its proponents' purposes. Callon (1991) introduced the term 'intermediary' most dominantly to refer to a faithful implementer of a proponent's wishes. Miller and O'Leary (2007) later adapted Morrison and Morgan's (1999) term by referring to 'mediating instruments' with the same meaning as 'intermediary'. However, accounting research has not developed much as to how accounting can play a less faithful role during trials of strength. The distinction between intermediaries and mediators (Latour, 1994, 2005) captures this dynamic about degree of faithfulness. When it is an intermediary, accounting plays only a faithful role in transmitting accounting information that people use to accomplish their goals. However, when it is a mediator, accounting translates goals with an unfaithful impact (Latour, 1994, 2002), or what Callon (1998) sees as a "potential conduit for overflows" (p. 254). Notwithstanding, a gap remains in the literature to better understand the role of accounting amongst the forces that can change or terminate strategic directions (Ahrens, Ferry and Khaliffa, 2017) by making an alternative option stronger or weaker. In an effort to address that gap, our work uses ANT as a frame to provide focus on the conditions in which accounting inscriptions may be faithful or otherwise and how different types of trials feature in situations of controversy around strategic options for organizational change. 
Going back to the origins of ANT in the early 1980s, the terms 'trial' and 'trial of strength' appear in several publications (Callon, 1986; Law, 1987; Callon, 1987; Hughes, 1987; Latour, 1987, 1988, 1994; Akrich et al., [1988](2002). Callon (1986) was quite early to relate the concept of 'trial of strength' to translation and interessement in his study of research on cultivation of scallops in St Brieuc Bay: "The scene is set for a series of trials of strength whose outcome will determine the solidity of our researchers (sic) problematization" (p. 207).

The terms 'trial' and 'trial of strength' were metaphoric descriptors associated with the means of translation that alters identities and relations between actors. "For Latour, the world is a field of objects or actants locked in trials of strength" (Harman, 2009, p. 16) such that "nowhere can we escape from the consequences of the translations and trials" (Latour, 1988, p. 147) since "there are only trials of strength, of weakness. Or more simply, there are only trials" (Latour, 1988, p. 158).

Despite the crucial importance of 'trial of strength' to the Callonian and Latourian literature ${ }^{1}$, these terms have been used to describe two different, but related, things. First, and as also noted above, 'trial' can be a test of a prototype against predetermined benchmarks of performance. Second, and equally important to our argument, 'trial of strength' involves two opposing forces in which an outcome of win-lose may emerge such as between two boxers (Latour, 1987) or between two mutually exclusive claims about some state of affairs, for example mutually exclusive decision options concerning organizational change and strategy for the future. In this organizational change context, resorting to status quo is not an option. There are two imagined, mutually exclusive options for the future, that become contested and only one will survive - either in its original form or

\footnotetext{
${ }^{1}$ Evidencing the importance of this concept, Latour's seminal work "The Pasteurization of France" (1988) as translated into English from the original French, uses the phrase 'trial of strength' 44 times and the word 'trial' in the absence of 'of strength' 32 times.
} 
modified during the trial. This trial can be labelled a trial of incompatibility. Having recognized these concepts, we are guided in our empirical inquiry by the following research question: How do accounting inscriptions perform in trials of contested organizational change?

\section{Methods and data sources}

The case presentation below has been based on archival and interview data using ANT based principles that follow the actors and the accounting inscriptions in circulation (Latour, 1987), seeking to provide a description: "that should trigger in a good reader this reaction: Please, more details, I want more details." (Latour, 2005, p. 137). By following the actors, we identify chains of associations consisting of people and inscription devices, notably accounting calculations on spreadsheets, documents and how these circulate within and across organizational boundaries in the case. The aim of our case-based method is to reconstruct and describe the chain of related events while providing a sense of authenticity derived from interviews and documents (Golden-Biddle and Locke, 1993).

The case's process and key features should become visible to the reader as we unfold the case exposition and our theory-informed analysis together. Of interest is to describe the actions and events surrounding sourcing strategies: i.e. to describe the economic experiments, trials and controversies where accounting inscriptions were implicated. Whilst the protracted nature of the case has made data gathering quite challenging, a strategy of relevance and cross-validation was followed focusing on the key events in the case. Data was drawn from a mix of interview and archival sources. Some interviews covered the full period studied whereas others provided partial coverage as was the case for most archival data. Collectively, the interviews and archival data provided should be evaluated on the premise that we are able to make a case-study description that allows for explanations to emerge rather than being imputed by through theoretical pre-determined 
categories regarding actors' roles and identities. As Latour (1991, p.129) suggests: “The explanation emerges once the description is saturated." It is not always easy to judge when the description is saturated, but we find that we have a sufficient empirical base from which to narrate our case exposition. We find that our description is reasonably saturated. Should we provide further description it would be to follow other networks and translations, which is not necessarily to the point given the research task that we set out to investigate; always there is a pragmatic delimitation to be made. Since the events had, in some cases, led to forced redundancies of key actors, document studies supplemented with interviews were deemed to be the most suitable means of extracting data that necessarily involved elevated levels of sensitivity. During these interviews as researchers we sought those precious moments: "allowing the researcher to connect, in some ways, with the interviewee's interpretive schemes" (Dai, Free and Gendron, 2018, in press). This is sympathetic to ANT's principle of agnosticism (Callon, 1986) and its means of describing actor's cognitions which may involve strong emotions such as when concerned groups feel excluded (Callon, 1998).

One or two interviewers conducted the interviews about actions and events and each initial interview followed a general approach where the starting question was a request for an explanation as to when and how the interviewee became part of the outsourcing process including its antecedent considerations. Interviewees were asked to tell the story of how they saw the process from their angle: what happened when and where, who was involved, what kind of actions were done, by whom and whether those actions concerned experiments, reports, memos, calculations, tenders, expert opinions and the like. Where interviewees touched on matters that they saw as being controversial, they were asked to describe how those situations emerged, what they saw as being the contested issues, what kind of views were being circulated and what calculations were being made and by whom. The interviewees were all well versed in the operations of facility management and 
several were also involved in calculating and estimating budgets as well as writing up reports within this domain. The interviewees were also active in the debates about calculations being made and distributed.

We sought to map the distribution of the calculations and their effects. We were especially attuned towards the calculations' faithfulness or unfaithfulness in supporting and/or undermining strategic options. From this approach emerged a rich view of how interviewees saw issues emerging among other participants and how calculations were being presented and with what effect in the opinion of interviewees. The interviewer also asked further specific follow-up questions where required to clarify particular flows of actions and events. Arising from the interviews and prior investigations, was the need to access multiple documents, as noted below.

After the initial interview, follow-up interviews related to specific issues were arranged when required; those subsequent interviews also tended to generate what Lincoln and Guba $(1985,303)$ call "prolonged engagement" and they managed to uncover additional information and a range of documents of significance. Concepts of authenticity and plausibility (Lukka and Modell, 2010) were mobilized in the interrogation of both interview and archival data such that sufficient levels of confidence were derived. As the key features of the case emerged, some additional, nuanced aspects were verified in additional interviews, including some new interviewees, by way of telephone, inperson and/or email. These supplementary interviews were also held where archival data seemed in contravention with initial interview data or had opened up new avenues of enquiry. Interviews were conducted with the 16 informants shown in Table 1 ranging from 20 minutes to 1 hour 45 minutes in length. To our best understanding these informants along with the many documents collectively provided saturation and details that allow us to reconstruct actions and events during the six-year 
timeframe of the case-study. A feature of the informant-sourced data is that most informants had extensive experience in the organization or role/s relevant to the case. Many interviewees had military careers exceeding two decades and, afforded assurance of anonymity, could impart rich contextual appreciations of the case circumstances. One caveat is acknowledged: One key participant supporting outsourcing did not participate despite several requests for an interview. However, our interview-based data is sourced from a slight majority of actors who, at various times, were opposed to outsourcing; yet, actors changed in their support or opposition and so our interview data complements the available archival data in a significant way by adding detail to the dynamics we aim to describe.

As noted above, some interviewees had lost their jobs due to outsourcing by the time we were conducting our interviews. This created the risk of post hoc rationalization in the recounts and so some interview strategy precautions were taken. First, questions were not asked in the positive but instead interviewees were asked to recount their recollections and to opine on how accounting inscriptions were produced, received and used. Second, we identified more than one interviewee who was present at crucial meetings or members of the same organizational entity and we interviewed them within a strategy of verification across interviews and with archival sources. Third, we focused on factual questions, albeit to elicit interviewees' personal impressions, rather than asking our interviewees to interpret variables that might have been of a priori interest before data collection completion. Fourth, in the write-up of results, specific sections of drafts were forwarded to relevant participants for assurance of accuracy and, if possible, for indications of participant reflections that could induce additional data to present a coherent story. 
Whilst the interview data was invaluable, the inherent vulnerability of human memory and the possible presence of retrospective proclivity needed to be tempered by cross-verification with archival data whilst acknowledging that not all of the archive has been made available to us. Identification of actors' stances, as indicators of values and identity, was precisely part of the methods approach adopted here. Archival data are important enactments of reality as they play roles in the hands of actors. Analysis of the archival and informant-based data was undertaken by way of examination looking for patterns of confirmation and contradiction in actors' accounts of the actions and events related to the DDF outsourcing. Some documentary data sources were confidential in nature but most were publicly available sources or results of 'Freedom of Information' requests. Data impediments arose from commercial-in-confidence restrictions imposed by some consulting and industry sources but were counter-balanced in three ways: first, by conducting interviews with guaranteed anonymity; second, in some crucially important documents, by observing changes of draft of documents which indicated how some ideas progressed through meetings and consultations; and third, by conducting most interviews after interviewees had left public sector employment and thus had fewer impediments to open and honest revelations. 


\begin{tabular}{|l|l|l|}
\hline $\begin{array}{l}\text { Interviewee Code } \\
\text { (refer to Appendix A } \\
\text { for abbreviations) }\end{array}$ & Role/s in case & Notes \\
\hline FMS\#1 & $\begin{array}{l}\text { Colonel, Deputy CEO of DDF's } \\
\text { facilities services management }\end{array}$ & $\begin{array}{l}\text { Interviewed on four separate occasions after } \\
\text { retirement }\end{array}$ \\
\hline U\#1 & Union representative, 3F & One interview plus two separate email threads \\
\hline DCD\#1 & Chief of Defence & One interview after retirement \\
\hline DCD\#3 & Chief of Defence & One interview \\
\hline FMS\#2 & $\begin{array}{l}\text { CEO of DDF's facilities services } \\
\text { management }\end{array}$ & One interview \\
\hline MoD\#1 & $\begin{array}{l}\text { Permanent Secretary of State } \\
\text { within the Ministry of Defence. }\end{array}$ & Informal conversations \\
\hline SO\#1 & Home Guard General & Several informal conversations \\
\hline U\#2 & Union representative & One interview \\
\hline PSP\#1 & $\begin{array}{l}\text { Outsourcing provider (with own } \\
\text { company) }\end{array}$ & Informal conversations \\
\hline MoD\#2 & Major, MoD & Telephone interview \\
\hline DCD\#6 & DCD CFO & One interview \\
\hline MP\#1 & $\begin{array}{l}\text { MP for Social Democrats, } \\
\text { member of Parliamentary } \\
\text { Committee of Defence }\end{array}$ & One interview \\
\hline FMS\#3 & $\begin{array}{l}\text { Tendering manager of DDF's } \\
\text { facilities services management }\end{array}$ & $\begin{array}{l}\text { One telephone interview; held multiple roles } \\
\text { over the case }\end{array}$ \\
\hline U\#4 & Union representative, 3F & One interview; conducted outsourcing roadshow \\
\hline FMS\#4 & Commander, DCD & Telephone interview \\
\hline DCD\#9 & DCD CFO & One interview \\
\hline Table & Profie of & \\
\hline
\end{tabular}

Table 1: Profile of interviews and other non-archival data

The archival data consisted of more than 50 documents exceeding 1,000 pages in total derived from reports (and sometimes their prior drafts), White Papers, presentation slides from meetings, DDF Annual Reports, internal memos, emails, spreadsheets supporting calculations presented in memos or reports, newspaper articles, union letters, announcements, press releases, consultancy reports, Parliamentary hearings and legislation. Documents of supra-national organizations such as the EU and OECD, have also been drawn upon. As noted by Hammond and Sikka (1996) and Napier (2006), researchers need to recognize the limitations to their craft circumstances such as when the archive needs supplementation if events are very recent and controversial. Sufficiently comprehensive historical data is likely to be beyond that offered up from the archive and so the interview data was an essential complement to the archive. 
During the analytical stage, data was first ordered chronologically so that the sequence of events could be identified. Having gathered and ordered the extensive data described above, the task became one of how to theorize it. This was a complex and uncertain process passing through several stages of identifying a plot for the story. This occurred in consultation with prevalent theories where ideas were tested. In our case, the plot of the story was identified quite late in the research process when the ANT trials concept emerged as a lens with which to understand the protracted case. After examining the data, a time-line of actions and events was established. Theoretical concepts that could best describe the flow and puzzles in the data were then considered. Since some groups were engaged in struggles with each other, the concept of trials of strength emerged as a relevant analytical approach. Hence, it became necessary to account for how the trials came about, where and when they became organized and the roles of accounting inscriptions in those trials. Tracing the accounting inscriptions, we were able to identify how they were produced, what calculations were used and circulated and with what effect. Arising from these methodological considerations, the presentation of the case study is described next.

\section{The case: Contested organizational change in the Danish military facilities services 4.1 Transnational push for public sector outsourcing}

Denmark began a march towards public sector outsourcing following 1980s recommendations by the EU Commission's to outsource services in the then public sector (Euro Strategy Consultants, 1996). In 1991, the Ministry of Finance (MoF) presented a comprehensive White Paper that estimated significant outsourcing savings based on OECD and EU experience. For example, in countries like the UK, USA, and Sweden savings were reported to be between $20 \%$ and $50 \%$. Further, and relevant to the DCD: "The American Ministry of Defence achieved around 40\% cost reductions" (Finansministeriet, 1991, p. 137). The MoF recommended Danish public sector 
outsourcing with reference to these calculations, i.e. they appeared at the time as strong evidence for outsourcing and in effect the accounting calculations played a role as a faithful intermediary for the international agencies and the MoF in promoting outsourcing.

From the mid-1990s, the MoF began calculating an 'outsourcing degree' (expenditure on outsourced contracts as a proportion of the agency total expenditure - both capital and recurrent) as a key performance indicator for each agency. This is indicative that potential cost saving inscriptions were insufficient to prompt change so the MoF needed further intermediaries to have outsourcing implemented. In 1996, the MoF reported to Parliament that a slow increase of outsourcing had taken place across the Danish public sector and that $19.9 \%$ of Danish outlays were in outsourcing contracts (Finansministeriet, 1996).

In 2000, the Outsourcing Council reported low compliance with the MoF's mandated outsourcing. However, it continued to promote outsourcing: "there is a broad consensus that tendering will be followed by savings ... (typically) of 15\%" (Udliciteringsrådet, 2000). This future and more costefficient world was based on an assumed causal relationship between outsourcing and cost efficiency: higher outsourcing degrees increase cost efficiency. The simple assumption relied on market competition in alignment with conventional neoclassical and liberal economic doctrines underlying outsourcing's theoretical foundation. However, while the Outsourcing Council hurried to proclaim a broad consensus regarding the saving potential, the Danish Defence Force (DDF) unique role and context were obstacles to their acceptance of the feasibility of outsourcing. The accounting inscriptions produced were not sufficiently persuasive to have outsourcing implemented, i.e. they became mediators and unfaithful in providing the effects they were set out to achieve. 
Whilst 22 years of argument constitute the overall case, we sharpen our focus on two major trials that become associated with two separate projects within the DDF. Eventually, after these trials (and more not reported upon here) a resolution emerged in 2013 which resulted in about 800 facilities services staff being transferred to private companies, leaving only a few remaining staff to monitor large outsourcing contracts. Here, we trace transnational outsourcing as it emerged and changed during two trials, implicating an increasing number of accounting calculations that were outputs of experiments conducted during those trials.

\subsection{DDF outsourcing project (PG-OUTS) leading to Trial One}

In 1996, the Defence Command Denmark (DCD) reported to the MoF that DDF outsourcing appeared to be amongst the more reluctant agencies. The pressure for compliance with outsourcing was unabated. As a consequence, the DCD included a specific outsourcing goal in DDF's "Vision 2010" 10-year strategic directions pronouncement in 2000: “The DDF will focus on core areas and optimize and develop the company, among other things by outsourcing of a limited number of service functions" (Forsvarskommandoen, 2000, 22). This goal was formal recognition that outsourcing was part of the DDF's external environment and, importantly, that some current activities were peripheral, or non-core, to the military effort.

Notwithstanding outsourcing support of the MoF and its Outsourcing Council, DDF officers, like the Chief of Defence, were concerned that outsourcing of facilities services would threaten military capability and security (DCD\#1). A long held military maxim advanced by Napoleon is that 'an army marches on its stomach' and so facilities services such as catering are considered 'core' military activities. Therefore, the Chief of Defence approached outsourcing issues with caution, notwithstanding that he was approaching retirement (DCD\#1). 
We pick up our case from 2000 when the pressures for DDF outsourcing could no longer be ignored. Nevertheless, the DCD wanted reassurance and detail on how outsourcing could be applied to its unique military context. In a sign of this caution, the DCD established a project called Project Group Outsourcing (in original Danish: 'Projekt Gruppe Udlicitering'; herein termed 'PG-OUTS'). PG-OUTS was tasked to assess the feasibility of facilities services being outsourced using a single barracks as an experimental site. These services included cleaning, catering and facility maintenance. PG-OUTS reported to Defence Command Denmark (DCD) with proposals to the Ministry of Defence (MoD) and Parliaments' Committee of Defence. The MoD and the MoF were responsible for operational efficiencies and budgets.

PG-OUTS was a temporary organization, resourced with a dedicated budget for two years during 2000-2002, staffed by four full-time military staff, and an economist under a Lt. Colonel. The project members extracted operational data from the barrack's records for 16 tasks ranging from canteen operations through to telephone and postal communications. Data about the number and size of buildings along with the number of relevant employees was compiled. In addition, facilities staff were interviewed, and their written observations diarized. Finally, direct cost estimates for wages and materials were based on "prior experience" and included in a budget baseline for the year of the study (2002).

PG-OUTS also sought estimates from contracting advisors to gather price data from private providers. Without formal tenders, the advisors estimated costs if services were outsourced; however, PG-OUTS did not form an opinion as to whether 'a market' existed for the provision of facilities services in a Danish military context. The project worked under the legal expectation and the theoretical assumption that if external prices showed lower costs compared to the insourcing 
option (labelled 'internal optimization'), then ceteris paribus, outsourcing would be favoured. Conversely, and in an important turn of events, the project group also begun to calculate a new and competing decision option: if external prices were comparatively higher, an 'internal optimization' decision would be favoured (FMS\#1). With this emerging turn of events, the prototype trial shifted into a trial of incompatibility: a trial between two mutually exclusive options.

Twenty-one months later (June 2002), PG-OUTS concluded with a comprehensive report and two important spreadsheets that later garnered much attention. These showed that internal optimization would reduce costs (net of revenue earned from food sales) by $19 \%$ four years into the future compared to the current estimated cost (refer Exhibit 1). In contrast, outsourcing savings would yield only $6 \%$ reduced costs after four years, and a maximum of $11 \%$ after five years (refer Exhibit 2) (Forsvarskommandoen, 2002a, Appendix 6, 45). PG-OUTS also recommended: "after 4 years, the outsourcing option can be reconsidered."

\section{TAKE IN EXHIBITS 1 AND 2 ABOUT HERE}

PG-OUTS' outputs were a significant surprise in that the project had been established to verify how outsourcing could apply to a single barrack, but it later recommended internal optimization in preference to outsourcing. This evidenced an emerging counter to the longstanding and international support for outsourcing.

In outlining the practical elements of its emerging organizational change strategy, PG-OUTS's report was comprehensive. Its optimization plans presented detailed documentation of facility service tasks; clear specification of future operational improvements; and, a path towards 
substantial investment in education and training of facilities services staff without additional funding required from the DCD's budget. ${ }^{2}$ The internal optimization option, was not just 'more of the same', it was not a routine proposal. Rather, this proposal amounted to a comprehensive organizational reform of the facility services operations and its 800 staff. It involved major investments in training to develop multi-skilling of staff across all defense facilities in Denmark and thus was recommending the opposite of the typical divestment strategy that may accompany outsourcing. From these investments the report promised significant future staff cost savings and service quality improvements, all of which had been negotiated with relevant unions (DCD, 2004; $\mathrm{U} \# 4)$.

With the presentation of its report and workings, PG-OUTS did not recommend outsourcing. Instead, it presented a business case for outsourcing and demonstrated its weakness by way of accounting inscriptions. Further, it did more than that: it also submitted accounting inscriptions and rationale to support a plan to internally optimize, that is, to continue insourcing and, surprisingly to the MoF, to invest more in insourcing. In mobilizing alternative accounting calculations to those made by MoF, EU and OECD in their generic and non-Defence workings, PG-OUTS signaled a forthcoming trial of the relative strength of two alternate strategies: outsourcing vs internal optimization.

Arising from PG-OUTS was an accounting calculation wherein location-specific operational cost data established a baseline drawn from budget data modified by engineering and time-and-motion

\footnotetext{
${ }^{2}$ Although not highlighted in the spreadsheets, the report noted that central funds would be available for investment in staff training.
} 
data. This baseline formed the common point of reference for a comparison of predictions projected over six years for each of the two organizational change options; however, the outsourcing option was still based on a theoretically informed and assumed market for military facility services.

The PG-OUTS report also argued that the private provider's profit would probably exceed the saving and this could be captured in addition to the quantified efficiency gains: "the savings from the outsourcing model must however also cover the profits of private providers which will not accrue to the DDF" (Forsvarskommandoen, 2002a, p. 43). The report did not discuss the profit nor specify how it could be captured under the optimization option however an appendix (refer Item G in Exhibit 2) estimated a constant provider profit with the effect that attention was drawn to an inherently additional cost only incurred in outsourcing. As one interviewee noted the: "profit estimate was considered to be a risk margin protecting the provider in case things went wrong" (MoD\#2). As shown in our annotations to Exhibits 1 and 2, other aspects of the comparison made the optimization option appear more attractive. Yet, there is a story to this. PG-OUTS also demonstrated an argument in favor of outsourcing; for example, "we expected that a private company would be more creative in boosting sales" (MoD\#2) and this was included in the spreadsheet. However, it was in an early comparison of the two options whereas the assumed growth of sales only appeared in the final report's optimization spreadsheet (Exhibit 1). The reversal of the expectation regarding sales is indicative that PG-OUTS was not an independent actor since the military was behind the report. It had an agenda in which calculations were presented. As we have also shown, the agenda was also transformed during the process of calculating the different options in the successive versions of the spreadsheet. 
The PG-OUTS work (Forsvarskommandoen, 2002a and 2002b) generated a trial of incompatibility. In subsequent events the trial continued during two briefings to discuss the report: one with the generals and one with the Minister. In both cases there was agreement with PG-OUTS but it still needed testing with the wider audience of the MoF and MoD. A high-level meeting was scheduled in July 2002 with six of the military's most senior relevant decision makers: the Minister of Defense, the Permanent Secretary for Defense, the MoD's accounting department senior manager, an Admiral with responsibility for facilities services, the Chief of Defense, the DCD Chief of Staff, and PG-OUTS' commander. During the meeting, it became clear to the MoD senior accounting manager that s/he would be disappointed since the project would not endorse and implement outsourcing.

At the meeting, the report was presented and concluded that a decision to internally optimize before outsourcing would generate the savings the Minister sought. In support, PG-OUTS' commander was even more optimistic, noting that the "savings estimate of $19 \%$ was the lowest possible but $25 \%$ savings could be achieved from optimization alone without outsourcing” (FMS\#1).

Reconciling opposing claims about outsourcing and public sector cost efficiency was difficult but PG-OUTS's accounting inscriptions provided sufficient evidence to lay a foundation. In addition, two further arguments appeared during the discussion. First, PG-OUTS' advisors were cited (MoD\#2) to advise that without optimizing operations before assessing outsourcing, an internal control bid could not protect against excessively high market prices (Forsvarskommandoen, 2002a). Second, looking beyond the accounting inscriptions, the DCD CFO argued that outsourcing would require bothersome accounting system change necessitated by establishment of a new, separate organizational entity to manage the outsourcing arrangements. Thus, the trial settled with 
optimization in the ascendancy due to three powerful arguments: greater projected savings; a prerequisite to future outsourcing; and, implicit simplicity in administrative arrangements.

As the decision meeting progressed, the senior manager of the MoD' accounting department expressed disappointment and argued strongly against the report's analysis and conclusion. At one point the accounting manager became "almost hysterical" towards the PG-OUTS commander when learning about the increased investment in facility services (fixed costs of employee education at the barrack under study). According to FMS\#1 the accounting manager "disputed the report's calculations and asked a 1,000 questions, but was asked to stop by the Minister who argued that the calculations were not made by the military alone but by independent consultants and clearly showed larger cost savings based on internal optimization". In the end, the Minister supported the recommendation to reject outsourcing in lieu of internal optimization, (MoD\#1). However, that decision managed to enlist new support and also create new opposition.

An important outcome of this trial was that PG-OUTS was formally tasked to implement optimization across all Danish military barracks. As such, the project had succeeded in establishing itself as a detour to outsourcing. That is, in a trial of two incompatible options, internal optimization succeeded and outsourcing failed. But this unexpected goal translation was not without further consequences since strong negative emotions emerged from those who had supported outsourcing (MoD\#1). Ramifications were wider than expected by the team working in PG-OUTS:

"After the meeting, I was phoned by a Liberal Party member of Parliament's Defence Committee, and a party colleague of the MoF, a MP, asking me to send him a copy of the PG-OUTS report. During the conversation he also asked me why we did not just outsource right away because that was what he had expected." (FMS\#1) 
Summarizing this episode, including its trial, the MoF's prior calculations (Finansministeriet, 1991) and continued argumentation proved to be sufficient to envisage a future of DDF outsourcing which it did by means of a detailed study conducted by PG-OUTS. However, the MoF calculations and assumptions about cost savings were not sufficient to resolve the ensuing controversy. Its generic cost saving estimates opened the debate by generating new concerns about many different issues such as the 'core' and 'periphery' of military operations, security at its premises, the quality of facilities services and their economic efficiency. The MoF generic estimates did not consider alternative options where staff could play an important role to improve cost savings and efficiency. Thus, it was subjected to further problematizations and trial. The MoF was confronted with an alternative set of accounting calculations, the PG-OUTS calculations, which demonstrated higher cost saving potential (at least 19\%, if not 25\%) from internal optimization due to investments in its personnel while simultaneously using very detailed and location-specific military facility cost data. The PG-OUTS trial is a trial about incompatibility between two competing options that shows accounting simultaneously weakening the outsourcing calculations and promises of cost savings while developing an alternative and stronger option of internal optimization. For the outsourcing option it became a trial demonstrating weaknesses while for the internal optimization option it became a trial that made it strong due to the relative claims regarding cost savings. That is, the PGOUTS accounting calculations became a mediator that challenged the MoF, OECD and EU calculations and rendered these agencies weaker. This is also an instance of a versatile role for accounting: the calculations shifted the outsourcing option from appearing to be strong and convincing into something less impressive and weak. Simultaneously, while the PG-OUTS calculations were unfaithful to outsourcing they were faithful intermediaries to the agencies propagating internal optimization. 
However, outsourcing had not been eradicated: it survived in the Danish public sector and was still in the MoF's conceptualization of a 'modernised' public sector (Finansministeriet, 1991). Further, such an imagined future as optimization and staff education must be followed by delivery and evaluation. A subsequent trial awaited internal optimization, a prototype trial.

\subsection{Results of Trial One and subsequent events}

Embarking on optimization involved a significant separation from the status quo since reasons for fundamental divisions of labour were revisited by investments in extensive training and revised union agreements. The costs of that organizational change were substantial and reported later to be 120 million DKK (Lauth, 2009). These intermediaries were faithful during the years 2002 to about 2005 in favor of internal optimization. Whilst the optimization was undertaken, the forces supporting outsourcing regrouped. The optimization focused on removing staffing constraints by reclassifying and training existing staff. This implicated successes with labour union cooperation as noted by a union leader "PG-OUTS was very collaborative, and we really enjoyed working with them" (U\#4). As evidence of optimization successes, annual allocations from 2003 to 2005 for facilities services were progressively lower (FMS\#1).

Notwithstanding the successes of optimization, pressures for outsourcing rose unabated - mostly from the MoF and its Outsourcing Council. The MoF (Finansministeriet, 2005; OECD, 2005, p. 107) reinforced OECD advice that Denmark's public sector had: "substantial potential for further competitive tendering and outsourcing". The DCD was aware of these views: "we were presented with these things: the EU, the OECD and the Ministry of Finance ... the purpose was totally clear: they wanted outsourcing per se" (FMS\#4).-The DCD's view that outsourcing was more than an effort to optimize operations became piqued by the use of a very simple, yet blunt, single metric by 
which the MoF sought to enforce change: the 'outsourcing degree' as required from each Danish agency.

To the DCD, the outsourcing degree inscription was meaningless. Senior officers pointed out that highly capital-intensive entities like the military could have a declining outsourcing degree even when outsourcing actually increased (DCD\#3). However, the fact remained that the outsourcing degree was below average in the military (FMS\#1). The MoF was in no mood for technical niceties, it only needed action in the form of increased outsourcing. Further, the MoF began monitoring an additional inscription: headcount. Its expectation was that a modernizing entity would employ decreasing numbers of employees. The military officers felt frustrated that the outsourcing degree and headcount displayed a complete disregard of the military context and the location-specific operations and equipment on which the military relies. Again, we see how accounting inscriptions were becoming a conduit of strong emotions and concerns.

In April 2004 the Minister who had approved optimization in Trial 1 was replaced by the same politician who had expected outsourcing to emerge. This also marked a shift in MoD identity as it began to favor outsourcing, notwithstanding the opposition of officers. The promised savings from optimization were under scrutiny and the MoD presented a series of efficiency demands which equated to "about 500 staff being retrenched" (FMS\#1) in total by 2007. Within the DDF, these retrenchments were taken to be evidence that DCD and the MoD had concluded that optimization was not sufficiently effective: "we had not cut enough" (FMS\#4).

In summary of the developments after the 2002 decision to optimize, a series of attacks were encountered by the optimizers: the underperformance against a rising outsourcing degree was noted; 
the failure to report on savings delivered by optimization was taken as proof that optimization had failed to reduce costs; the relative stability in headcount was taken as evidence that the DDF was not modernizing; and, external providers of facilities services argued that they should be given access to the DDF's procurement practices. A particularly revealing incident in which actors' identities were exposed was a 2005 meeting, convened with the support of the Minister of Defence, senior defence officers/staff and CEOs of Danish cleaning companies. Here we see strong emotions arising from frustration on the part the same accounting manager who had challenged PG-OUTS' workings; s/he was startled to learn that: "PG-OUTS had been retraining DDF staff at a considerable cost to facilitate their multi-skill new roles" (FMS\#1). S/he "became very angry" (FMS\#1) about the size of investments in education in the optimization strategy. This is perhaps unsurprising since the training cost was not explicitly shown in the PG-OUTS spreadsheet. Whilst discussed in the report, a specific accounting inscription for training was absent since the DDF would be fully reimbursed and it had no budgetary impact on the DDF. Such consequential thinking was however taken as a sign of fault in the PG-OUTS report which was now under attack as its credibility was challenged and the new Minister was not a protector. That is, the PG-OUTS calculations were now under transformation from being an intermediary to become a mediator, and what we see as another instance of the versatile role of accounting in a trial of incompatibility.

A newly appointed DCD CFO agreed with the Chief of Staff in the clear view: "the [PG-OUTS]calculations were simply wishful thinking and not scholarly founded" (DCD\#9). Here we see that the data is not recognized as proof of cost savings due to internal optimization. The optimization managers did not perceive the threat; as one noted: "We were really busy at that time and we could not see the need for making a larger report [demonstrating savings], because it was all too visible that we had achieved [through internal optimization] what we set out to achieve" (FMS\#1). 
Although the internal optimization managers assumed that their annual operational budget reductions would be strong enough proof of goal compliance, that is, the assumption that the accounting inscriptions performed as intermediaries, these facilities services budgetary inscriptions instead were questioned and lost from the impending trial of optimization. This trial transported the prototype internal optimization from the test environment within PG-OUTS' spreadsheet calculations to the real-life test environment. In the end it became a trial of weakness due to accounting calculations serving an unfaithful mediator role. This outcome was a huge surprise to the internal optimization managers who thought they deserved recognition for their achievements. We theorize these surprising events as an instance of a versatile role for accounting in which accounting shifts its role from being a faithful intermediary to an unfaithful mediator because it became a conduit for new emerging concerns and strong feelings of being excluded; this is further developed below.

\subsection{Trial Two: small-scale tenders}

The attacks on the credibility of optimization led to MoD action to mandate market testing as provided for by EU tender law (FBE, 2006, 12 Dec.). The DDF was directed to identify sites suitable for market testing of an outsourcing strategy. This was significant in the eyes of the internal optimizers: "the MoD asked us to point out possibilities (for tendering), and then they were happy because then we were on the run" (FMS\#4). These tenders were limited in scope because they only involved five barracks out of a total of 170 barracks and only one service function by tender (canteen or cleaning) but their collective nature was designed to test a control bid against the market. The call for tenders commenced in 2006 and continued for the subsequent facilities until early 2007. The facilities services managers were nevertheless confident of winning this contest since they believed they were more efficient than in 2002 when outsourcing was already a higher 
cost option. However, they were soon to be observers to a startling reversal in the tests' foci and the outcome of the resultant trial.

Immediately prior to the five-tender test, facilities services management initiated a structural change establishing two independent units with a "Chinese wall" separation. One unit was to prepare tender responses in the form of a control bid whilst the other unit was to assess all tender bids. A strict ban on communications between the two units was imposed (FBE, 2006, 12 Dec.) as per MoF regulation. At the same time, PG-OUTS was terminated and its personnel transferred to the control bid preparation unit.

The five tenders' results are summarized in Table 2. Collectively these tenders amounted to a significant effort from the facilities service tendering unit, the DCD and the tendering suppliers. Each tender was carefully constructed with advisories regarding the tenders' legalities, negotiations with barracks commanders regarding the services, briefings to potential tenderers, assessments of tenders lodged and the final decision.

\begin{tabular}{|l|c|l|}
\hline $\begin{array}{l}\text { Tender (barrack } \\
\text { location) }\end{array}$ & $\begin{array}{l}\text { \% price differential: DDF control } \\
\text { bid relative to lowest tender }\end{array}$ & Outcome of tender \\
\hline Braband & $96 \%$ & Awarded to DDF on basis of control bid \\
\hline Avedøre & $96 \%$ & Awarded to DDF on basis of control bid \\
\hline Ballerup & $91 \%$ & $\begin{array}{l}\text { Contract issued to 3d highest bid (same score as } \\
\text { DDF, but awarded by DCD to external provider) }\end{array}$ \\
\hline Korsør & $178 \%$ & $\begin{array}{l}\text { Cancelled: no complying bid; DDF continued } \\
\text { internal provision }\end{array}$ \\
\hline Antvorskov & $93 \%$ & Cancelled; DDF continued internal provision \\
\hline
\end{tabular}

Table 2: Tender experiment results (FBE, 2007b, 13 Dec. and 2008c, 30 Oct.)

Over 26 months, the tenders managed to repeatedly demonstrate what the PG-OUTS report concluded: in-sourcing was the least-cost option when compared to the tendered costs thus a competitive market did not exist for military facilities services. Notwithstanding that clear result, 
the five-tender experiment didn't produce common ground. The DCD supporters of outsourcing ignored instances where the control bid was lower than the tendered bids. In such cases they concluded that the tender was poorly constructed and had not attracted a competitive market or that the control bid was "unrealistically low" (FBE, 2007a, 24 July). This was reinforced by private companies who accused the military of "lodging insincere control bids" (FMS\#2).

The supporters of insourcing were equally dismissive of some results. They judged bids below the control bid to be non-compliant to the tender (low quality or inadequate service provision). Further, both sides disputed the risk and uncertainty arising from whether claims for compensation would be payable if workers were transferred to private employment. A morass of outsourcing issues began to generate frictions and the various accounting inscriptions were not helpful in reducing the frictions but rather added to them:

"In the Ballerup tender we got the same scores as the external bidder. We saw that as a strong evidence of our internal optimisation strategy being a success. We had made our work processes much more efficient and thought the DCD would praise us for that success. However, it was like they did not want us to have success and in the end they gave the contract to the external bidder" (FMS\#2).

Different success criteria emerged regarding the tenders' role. For the outsourcing supporters, the tenders were intended to confirm the desirability of outsourcing, while for internal optimisation the tenders were expected to continue the data experiment began by PG-OUTS regarding the relative advantage of the two options. However, FMS managers began to suspect the MoD's sincerity:

"The DCD made it clear to me that it would have been very good if we had lost all the tenders. I could not understand that. I thought I was put in place to optimize and make tenders, and if we could win the tenders it would be good. If not, we were not just good enough. That is it." (FMS\#3)

The outsourcing supporters became increasingly frustrated as the tenders proceeded. Progress was slow: "The MoF and MoD considered that the process (calling tenders and evaluating the bids) was 
too slow" (DCD\#1). Furthermore, impatience was heightened by the many inconclusive results emerging from the five tenders even as DDF outsourcing fell from 2005 (19\%) to 2006 (17\%) (Forsvarsministeriet, 2007b, 14). In a preemptive but frustrated move, the MoD set a new outsourcing target of $20 \%$ by 2007 (Forsvarsministeriet, 2007a).

Attention turned to DDF's accounting systems with challenges to its cost data. "In the wake of the tenders, the control bid calculations were questioned including that a total cost calculation [Ed. specifically the allocation of indirect costs via activity based costing] had not been conducted" (FBE, 2007a, p. 1). In response, the facilities services' accountants (FBE, 2007a) recommended that the control bids should include an additional $15 \%$ overhead (10\% indirect costs and $5 \%$ risks). This seemed to be a proposal to placate the DCD. However, the facilities services top manager rejected the change because the responsible manager: "did not to have any persistence in fighting our case. He was promised promotion by DCD and therefore did not want to fight" (FMS\#1).

In a controversial move but in response to critiques of the control bids' accuracy and the Chinese Wall, the facilities services manager went outside the military. He commissioned the State Attorney to independently evaluate the control bid organization and the bids. The State Attorney subsequently confirmed the control bids' probity, but that advice was only of marginal effect since pressure continued to mount over the DDF's failure to outsource. The military officers became frustrated and used a military analogy: "it was ridiculous that we had to hire the State Attorney to prove that we did not fiddle the numbers. It is a crazy way of fighting, because we belong to the same company, and it made the Chief of Staff furious indeed" (FMS\#1). 
In a surprising twist, attention then turned to the small-scale tenders' tendering costs. When pressured for an overview of the five tenders, senior facilities management staff prepared a summary report drawing attention to the observation that "the multiple contracts with multiple suppliers incur high transaction costs including monitoring of contracts and service delivery" (FMS\#1). As quickly emerged transaction costs - especially tendering costs - became a point of agreement for both sides of the trial and were confirmed by external advisors' calculation that the "transaction costs are about 25\% of the turnover of the barracks" (McKinsey, 2008, p. 72).

Both sides of the controversy problematized costs of tendering. The facilities management staff saw these costs as excessive and only justified as being part of a "learning process" (FBE, 2008, 25 Sep., p.3) to demonstrate that a competitive market for military facilities services did not exist. Their report on the five tenders was reflexive in that it seemed to be the logical extension of the PGOUTS report and the subsequent investment in multi-skilling facility management staff: that is, outsourcing was not a way to reduce costs and so the internal optimization project should continue. The facilities management staff felt they were on firm ground since, based on the tenders' results (refer Table 2), they had actual data; as they said: "It is important to emphasize that in this case we are talking about 'actual' prices" (FBE, 2008, 30 Oct., emphasis in original). Although internal memos were noting transactions costs, in the form of cost of constructing the tenders, formulating control bids, and evaluating all bids, by October 2008 the facilities management staff were also receiving external advice that transaction costs were a problem for outsourcing: "there are fewer transaction costs by implementing fewer tenders" (Deloitte, 2008, p. 9). The costs of calling for tenders, preparing a control bid and evaluating all bids were estimated to be around 2 million DKK per contract (FBE, 2008, 14 Dec.) or an astounding 28\% of the tenders' average size. 
Whilst the facilities management staff saw the situation unambiguously, the prospective providers were severely disappointed that contracts did not emerge from the tenders (with the singular exception of Ballerup). They strongly argued their case to the DCD, MoF and politicians (COWI, 2008) that the small-scale tenders, and their proposed 30 contracts for separate services, were the cause of a problem (FBE, 2008, 30 Oct.). Further evidence of private provider disenchantment came with Denmark's largest provider (ISS) decision to submit non-complying "shadow bids" (FBE, 2008, 25 Sept.) as a protest that the contracts were too small for their commercial interest. Rather than ignoring the opportunity to bid, ISS drew attention to their claim that the tender process was flawed and used their "shadow bids" as means to demonstrate their displeasure but also strong interest. The outsourcing providers' failures to respond commercially to small-scale tenders amounted to a threat to kill prospects for any Danish military facilities outsourcing unless a largescale approach could be adopted.

As private providers began to complain about the unfair small-scale structure of tenders, unrelatedly (at that moment) the DCD and MoF approved a major review of the DDF's organization structure and strategy. With respect to facilities services, structure was not reviewed since the terms of reference developed into a stronger focus on whether and how the facilities activities should be outsourced. Curiously, in its briefings to the review, the facilities services management problematized its existing small-scale outsourcing strategy. For example, it wrote:

"The problem with the existing strategy, seen from the bidding companies' point of view, is that the tasks to be outsourced are not aligned with the preferences of the market. (The DDF) seeks to outsource at single barracks, but companies are specialized within areas such as cleaning. This, in turn, requires that prospective contractors must contract sub-suppliers in order to bid for the contract. They spend a lot of resources to stitch together a bid. This together with the circumstance that they only bid for one establishment, makes it less attractive. Relative to the expenses they incur, the profit they receive from running the operation is small. It is therefore necessary to consider the existing approach to outsourcing" (FBE, 2008, p. 2, 10 Oct.). 
That text was copied, pasted and edited into a power-point presentation prepared by the project manager (FBE, 2008, 12 Oct.). Consequently, after a series of review meetings designed to structure the organizational review, outsourcing strategy became the central focus of the review energy to be devoted to facilities services. Thus, the facilities services management noted to the staff that outsourcing strategy - as opposed to organizational design issues - was to be the single "area of in-depth study in order to advise on how to develop a future oriented strategy here." (FBE, 2008, p. 1, 10 Oct.).

The decision to focus the organizational review on outsourcing and the problematization of the small-scale nature being tested in Trial Two, were the first indications of what would become a subsequent process in which large-scale outsourcing emerged as the final solution. Embedded in the large-scale approach was an argument that transaction costs (tender preparation, briefing tenderers, preparing a control bid, evaluation and so on) were too high in small-scale outsourcing whereas large-scale outsourcing would have lower total transaction costs. The issue of transaction costs became paramount and overtook cost savings from outsourcing. As noted by a senior DCD officer later in our interviews: "When we choose large scale outsourcing, it was simply because of transaction costs" (DCD\#6).

As the 'organizational review' progressed it became apparent that a synergy between two concepts was in the ascendancy: large-scale outsourcing and transaction costs. The outsourcing providers' arguments that small-scale contracts were not attractive were soon combined with accounting inscriptions from the 5-tender trial. It is important here to note that those inscriptions came from the part of DDF supporting internal provision (via a process of internal optimization). Whilst the 
tenders showed internal provision to be the least cost option, they also showed very high transaction costs associated with small-scale contracts.

The decision to progress with large-scale outsourcing marked the beginning of the end of several years of internal optimization and small-scale outsourcing. The decision was not a compromise where outsourcing and internal optimization could co-exist. They became mutually exclusive options, where internal optimization and small scale-scale tenders were considered to be incompatible with large-scale outsourcing. The case for internal optimization coupled with some small-scale outsourcing lost due to challenges to its calculations and business case such that the case was brought into weakness by competing calculations and interpretations thereof.

To reinforce our overall findings, we briefly recall two surprising moments in the case. The first moment is where accounting calculations play an unfaithful role to make an option stronger: the 5tender results showing no competitive market and high transaction costs which would presumably make the outsourcing option weaker but to the surprise of many actors it instead resulted in making it stronger. Those results and calculations were worked recursively to weaken conclusions supporting insourcing while developing an emergent interest in scaling up the size of contracts to minimize transaction costs. In our case, transaction cost calculations play a versatile role. These calculations transform, from being a faithful intermediary when first calculated and issued by the supporters of internal optimization only to become an unfaithful mediator when circulated into the hands of the supporters of outsourcing. The second moment is where accounting calculations play a faithful role to make a strategic option weaker. The example of this is found in PG-OUTS' calculations that showed, to the surprise of decision-makers, that the saving potential from outsourcing was lower than the alternative of internal optimization. That finding was contrary to the 
MoF's views and other taken-for-granted views that outsourcing was a proven technology to release cost savings. Nevertheless, PG-OUTS' calculations acted faithfully to convince decision-makers that internal optimization was more interesting than outsourcing and they rendered the outsourcing option weaker than internal optimization. Also, in this second moment accounting played a versatile role by transforming a prototype trial of outsourcing to a trial between two incompatible options. This concludes our exposition of the protracted process of trials of prototype and incompatibility which led to the strategic organizational changes as are briefly noted next in the case epilogue.

\subsection{Case epilogue}

In consequence of the prototype trials and trials of incompatibility by the end of 2008 the various organizational change actors had reconfigured themselves and their identities. The most important was that the DCD became an advocate of outsourcing and abandoned its support of internal optimization. Additionally, the MoD moved further in its outsourcing aspirations to embrace largescale outsourcing. In the wake of the trials, supporters of outsourcing moved from indifference on number and scale of contracts to become identified with a small number of very large contracts. This solution was mostly justified by the argument that transaction costs would be minimized. Indeed, the term "transaction cost" came into the discourse and its persuasive ability pushed alternative questions into a quiet, dark corner. Such questions included: 'is outsourcing more efficient than internal provision?' is there a competitive market for facilities services in the military? Should facilities services be considered as core activities that need to be limited to internal provision? Such questions had dominated during the PG-OUTS trial but 'transaction cost' and the minimization thereof became new central issues of concern. 
The decision to implement large-scale outsourcing brought significant organizational change through two contracts covering all of Denmark: 800 multi-skilled staff, educated in PG-OUTS's internal optimization, were transferred to the private sector. With this decision, the trial of incompatibility ended and a prototype trial of outsourcing (beyond the scope of this paper) began. Thus, whilst the five calls for (small scale) for tenders failed to elicit evidence of a competitive private sector provider, the two large-scale contracts had the effect of creating private sector provision. Through Trials 1 and 2, organizational change eventuated: not in the shape envisaged in either of the trials at their commencement but nevertheless a change that was influenced by accounting inscriptions that variously behaved in ways that surprised or reinforced their propagators' positions, what we have conceptualized as a versatile role. With the above description of the protracted organizational change trials, the remainder of the paper discusses insights and contributions that may be drawn from the case.

\section{Discussion}

The ambition of this article was to elaborate on the concept of trials of strength by proposing a typology distinguishing between prototype trials and trials of incompatibility and by addressing the research question on how accounting inscriptions perform in contested organizational change. Below we consider in some more detail how our paper contributes to the literature and then conclude with some considerations for future research.

\subsection{On the distinction between prototype trials and trials of incompatibility}

There are several extant contributions concerning accounting where a trial of strength was reported; interestingly, these involve introductions of new accounting systems (Earl, 1978; Briers and Chua, 2001; Miller and O’Leary, 2007; Preston et al., 1992; Revellino and Mouritsen, 2009). These cases 
involve what we characterize as trials of a prototype. We supplement these earlier contributions by considering the distinction between prototype trials and trials of incompatibility and the related questions for a public sector (out) sourcing case.

Notably, we consider our case to be an exemplar of both a prototype trial, i.e., a singular change promoting public sector outsourcing, and a trial of incompatibility, i.e. a change involving incompatible options where one option will prevail over an alternative option. We argue that our case captures both types of trials of strength, of weaknesses. Initially, the case appears to be about singular sector change - a prototype trial - promoting public sector outsourcing. However, further in to the process and events, the trial transforms and becomes a more heterogeneous case of trials of incompatibility regarding mutually exclusive options: either outsource now or optimize. The decision context transforms accordingly; it becomes less homogenous/more heterogeneous due to this new emergent trial of incompatibility between two incompatible decision options. In further trials, also incompatibility regarding methods (small or large scale outsourcing?) emerges, only to conclude (provisionally) with a more stabilized/more homogeneous decision context: Outsourcing big-bang, first with two contracts, and finally only one contract (i.e. a very homogeneous/monopolistic decision context).

We traced the process of trials of incompatibility and the detour it entailed regarding goals and means and showed how strength was reversed into weakness. The trial of incompatibility is a tiered array of weaknesses. Preston et al. (1992, p. 579) noted the possibility of resistance to a prototype as being more than resistance to change. We complement them by proposing that trials of incompatibility can manifest resistance to change as the formulation and development of incompatible change options, enriching our understanding of resistance to change as being mutual 
and in dynamic transformation. As ideas for change cross from one tier of weakness to the next, more actors attach to the option for change suited to those ideas - subject to their identity being congruent with the ideas. For example, outsourcing's weakness was its inability in both Trial One and Trial Two to demonstrate least cost. However, as the idea of transaction cost survived with least weaknesses, outsourcing emerged as being a winner in a large-scale formulation that mutually excluded internal provision.

The extant literature on accounting in organizational change invokes trials but has not yet extended that important and fundamental concept by considering types of trials. Applying the characterizations of prototype and incompatibility as we do, creates the prospect of improved understanding of how accounting can sometimes be faithful or unfaithful to its proponents. Although Miller and O’Leary (2007) identified actors' strong disagreements in the semi-conductor industry, their story is actually of prototype trials where accounting enabled the change-option to become strong. What we can show is that strength grows from weaknesses during a trial of incompatibility where accounting contemplates other roles than an enabling role or as a mediating instrument. This we will discuss in further detail below.

\subsection{Accounting as mediating instruments and the versatile role of accounting in trials}

As noted by Miller and O’Leary (2007) and Miller and Power (2013), accounting can play a mediating role and be coupled to intended outcomes (goal/end) to varying degrees. We complement their contributions and others (Christner and Strömsteen, 2015; Jeacle, 2009; Jordan et al., 2013) by showing how actors mobilize accounting. In our case it was with respect to efforts to make DDF's facility operations more cost effective. The versatile role of accounting, that is, the dynamic shifting of accounting inscriptions between performing the role as intermediary or mediator, helps us 
understand the case's dynamics where implementation of a strategic organizational change became one of goal translation and detour. Versatility refers especially to situations when a prototype trial of implementation morphs into a question of whether that change is worth implementing, and eventually when alternative proposed changes emerge through a trial of incompatibility. A trial of incompatibility coupled with versatile accounting inscriptions demonstrate the dynamics of how strength transforms into weakness, and vice versa, and detouring strategic organizational change.

In part, our case resembles instances conceptualized by Burchell et al. (1980) regarding the role of accounting. However, while the discussion of Burchell et al. remains within each quadrant of the typology, we trace the connections and dynamics across the typologies in that quadrant. For example, we have shown that Trial One was entirely about incompatible goals whereas Trial Two was both about incompatible goals but also about incompatible methods or/and means. This is not just a case of being either an answer machine, or ammunition, or learning, or ex-post rationalization. Instead, the accounting inscriptions can variously perform as combinations of these categories and thus be said to be versatile. As an answer machine, the accounting calculations backfired on those who launched them and turned into an ammunition machine. Also, the ex-post rationalization machine was hardly found in our trials because nobody knew from the outset if and eventually how an (outsourcing) option would become decided and implemented. It is only after a decision and change implementation that ex-post rationalization calculations could be made and circulated. Further, decisions that are made may also be weakened, re-made and transformed due to the versatile role of accounting which can be associated with surprising moments.

In the case's surprising moments, clarity is provided regarding the versatile role of accounting and how accounting can become mediators (Latour, 1994, 2002, 2005) and a conduit for overflow 
(Callon, 1998), which is different from the role as a faithful intermediary/mediating instrument. Conceptualizing the ability of accounting to move between being faithful or being unfaithful to its proponents is also a means by which to contribute to other literatures which we do in the following brief subsection as an indication of fruitful future study.

\subsection{Contributions to governmentality and understandings of change}

Sociologists grappling with the human project have sought answers to societal and organizational change such as whether human society has, or has not, shifted between modernity and postmodernity (Callon and Latour, 1981; Latour, 1993; Miller and Rose, 2008). Although these authors invoke forces much larger than accounting per se, the influence of accounting on such macro changes should not be underestimated (Miller and Power, 2013) and in that regard our work can be an important explanator illuminating how accounting can associate and attach with various forces including accounting itself - so as to influence changes in society.

We have observed in our case that accounting inscriptions are not always compliant to their propagators' intention - they do not stay faithful and only play a role as intermediaries, but can become unfaithful mediators. It is that versatility of accounting which contributes to its ability to associate with other forces (for example, new public management, economic theories, social movements, concerned groups and similar). In the kernel of this observation lies a contribution to concepts of governmentality.

Miller and Rose (1990) developed Foucault's (1977) concept of 'governmentality' as a means of describing "the role accorded to 'indirect' mechanisms for aligning economic, social and personal conduct with socio-political objectives" (1990, p. 2). They show how accounting facilitates, in an 
intermediary/mediating role, action at a distance which can add disciplinary direction to organizational (and individual) participation in society. Accounting can be active in establishing knowledge:

'"Knowing' an object in such a way that it can be governed is more than a purely speculative activity: it requires the invention of procedures of notation, ways of collecting and presenting statistics, the transportation of these to centres where calculations and judgements can be made and so forth. It is through such procedures of inscription that the diverse domains of 'governmentality' are made up, that 'objects' such as the economy, the enterprise, the social field and the family are rendered in a particular conceptual form and made amenable to intervention and regulation." (Miller and Rose, 1990, p. 5).

The contribution of our study to governmentality is to explain that accounting inscriptions cannot be relied upon to act faithfully to the interests of their proponents and that instances where accounting may or may not be faithful are shaped by trials of strength where trials of incompatibility will often be marked by an increased number of inscriptions. Governmentality is not challenged by these observations, but it is enhanced by the recognition that major reforms are fragile developments that will require constant investments to assist accounting inscriptions issued by reform advocates. Further, as shown in the case we discuss here, despite investments it is possible that the reforms will be detoured to the point where advocates may consider them to be deformed and debased by the unfaithful accounting inscriptions. Thus, the shape of governmentality is not guaranteed but instead we see that accounting is needed by actors to have their ideas and goals come through - and that those ideas and goals are also shaped during trials of incompatibility by accounting calculations that shift in unpredictable ways between degrees of faithfulness. The notion of a versatile role captures these dynamics.

An additional reflection on the contribution to governmentality relates to emotion and how accounting inscriptions can be conduits to changed emotion. Callon's (1991) term 'intermediary' 
points to dynamic and transformative mechanisms which Callon (1998) explicated more directly when identifying inscription devices as conduits for overflowing. We agree with that and note that important overflows can be altered emotions, for example among emerging concerned groups feeling excluded (refer, Skærbæk and Tryggestad, 2010). Arising, like Bourmistrov and Kaarboe (2013), Boedker and Chua (2013), and Baxter, Carlsson-Wall, Chua and Kraus (2018) we recognize the need for more research on the emotional dimensions of human-non-human associations in actornetworks. Our case analysis also shows that the emotions are dynamic; joyful feelings of success can be replaced with feelings of betrayal, exclusion, despair and failure. These emotions are not independent of the accounting inscriptions, but rather seem to be closely associated with a versatile role of accounting during the protracted trials of strength, involving both prototype trials and trials of incompatibility where accounting inscriptions influence emotions and vice versa.

\section{Conclusions}

This article reports on a case where an organization being asked to change could not initially see the change being consistent with its longstanding identity. As accounting inscriptions, such as 'outsourcing degree', were applied against it, the organization's frustration with the inadequacy and isolation of such measures became palpable. That frustration and the inability to simply ignore pressure for change led to an internal search for new accounting inscriptions: "resistant local knowledge ... mobilized against the new calculable space - changing the trajectory of events" (Vaivio, 1999, p. 689). The search for validation of outsourcing and strategies to implement it produced a report (PG-OUTS) that initially set out to test a single prototype idea, outsourcing in the military, but ended in testing two incompatible ideas (outsourcing and optimization). However, the proponents of outsourcing were not to be denied and they mobilized further inscriptions in a fivetender test and transaction cost considerations dominated even though outsourcing was not shown 
to be least cost. The role of accounting inscriptions in these events has been shown to have been versatile and at times faithful (i.e. intermediaries) but at other times unfaithful (i.e. mediators). Tracing the behaviors of intermediaries and mediators presents a means of unlocking the hidden narratives that, when revealed, will assist to explain how the affective nature of accounting (Boedker and Chua, 2013; Baxter et al., 2018) influences overflows that surprise propagators and opponents of organizational change.

The experiments during the trials of incompatibility resulted in paradoxical outcomes that contradicted the theoretical underpinnings of outsourcing as a source of least cost. We see that strategic decision making on sourcing options can be unexpectedly controversial, costly and prolonged with hotly contested goals notwithstanding the predominant literature on the advantages of outsourcing. Further, whilst being based on a theoretical assumption of the efficiency of markets essentially arising from competition, implementation of outsourcing can produce a duopoly - and even a 6-9 year monopoly. Interestingly, at least in the case discussed here, public sector outsourcing appears to undermine the assumption of competitive markets upon which it is premised.

The accounting literature has devoted significant resources to management control of outsourcing arrangements with less effort given to understanding the process that led to outsourcing. It is surprising that critical accounting research has so few studies on how business cases and decisions for/against outsourcing are made. Rather than assuming decision making is driven entirely by cost and risk factors, we would welcome more research on the dynamic processes of sourcing experiments, calculations and decisions. 
Notwithstanding our contributions, future research could attempt to redress some of the inherent limitations to our work. One such limitation relates to the single and idiosyncratic organization, the DDF, from which our case data was drawn. The DDF has a very long and unique history which makes it different from other organizations. Thus, future research should consider trials in any other organizations to (dis-)confirm or qualify our results. In particular, future studies should be based on extended case studies in which a series of trials can be traced in non-military organizations. A second limitation arises from the role of consultants as expert advice-givers in our case: the dynamics of our case may have been unduly influenced by the extensive use of consultants by both sides of the outsourcing controversy. Whilst we have treated these sources of information and argumentation no differently than other sources, there is the possibility that 'experts' bring an added dynamic to trials such that their advice may achieve a privileged status. Accordingly, the growing literature on consultants could benefit from studies that closely examine the influences of multiple consultants during a series of protracted trials. A third limitation to our work is that the intense controversy of the case may have caused some barriers to be erected to prevent access to overly sensitive data. The scale of the outsourcing and its nature which combined national security together with 'value for money' aspects of public administration, may have restricted access to archives and reduced interviewee candour thus sanitizing some issues. A less prominent case with less significant implications may be suited to reveal added information and so would be useful to confirm or qualify our findings.

An overall message from our research is that the analytic concepts suited to understand contested organizational change need to be used in nuanced manners in order to achieve their objective. Whilst trials of strength have been mobilized in prior literature, future studies should conceptualize the implications of different types of trials and should also look for signs of the versatile role of 
accounting in that its inscriptions may switch between being faithful or unfaithful to their proponents. Additionally, our research shows that controversial issues may not be resolved without significant investment and even after such investment, the change may be detoured and reshaped to the surprise of actors involved in the trials. 


\section{Appendix A: Abbreviations:}

\begin{tabular}{|l|l|}
\hline DCD & $\begin{array}{l}\text { Defence Command Denmark: the command structure in control of the military forces of } \\
\text { Denmark including coverage of insourcing/outsourcing policy setting }\end{array}$ \\
\hline DDF & $\begin{array}{l}\text { The military forces of Denmark: army, navy and air force including the provision of } \\
\text { facilities services }\end{array}$ \\
\hline DKK & The Danish monetary unit, Danish Krone, equal to approximately 0.075 Euro \\
\hline FBE & Facilities Management Unit (within DDF; an archival source for this research) \\
\hline MoD & Ministry of Defence \\
\hline MoF & Ministry of Finance \\
\hline PG-OUTS & Project Group-Outsourcing (in DDF) \\
\hline
\end{tabular}

\section{References}

\section{Primary sources}

COWI, 2008. Erfaringer med udbud af Facility Management (FM) i FBE, 5 Dec.

DCD, 2004. Aftale B, Uddannelsesaftale mellem Forsvarskommandoen og fagforeninger. Available at:http://forsvaret.dk/FPT/Nyt\%20og\%20Presse/Documents/Institutionsspecifikke\%20bestemmelse r\%203F\%20(underskrevet)\%20DOK392520.pdf Accessed 11122014.

Deloitte, 2008. Vurdering af praksis i forbindelse med udbud og kontrolbud af Facility Management ved Antvorskov kaserne. 6 Oct.

Euro Strategy Consultants, 1996. The single market review series - Subseries III - Dismantling of Barriers: Public Procurement, July.

FBE, 2006. Udkast til notat vedr. afgrænsning af Facility Management (FM) udbud.

Kvalitetsdivisionen (2nd draft). 8 Dec.

FBE, 2007a. Notat vedr. omkostninger i kontroludbud på Facility Management, Økonomisk

Sekretariat, 24 July.

FBE, 2007b. Dokumentnotat vedr. Indstilling om valg af tjenesteydelser, FM ved FMT - Ballerup.

13 Dec.

FBE, 2008. Review af Forsvarets Bygnings- og Etablissementstjeneste foreløbige forslag til fokusområder. 18 June.

FBE, 2008. Udbud facilities management, 25 Sept.

FBE, 2008. Fokusområde 1 - bemanding i forhold til opgavekompleks. Ledelsessekretariatet, 10 Oct.

FBE, 2008. Kære kollegaer i FBE, Ledelsessekretariatet. Brev til personalet, 10 Oct.

FBE, 2008. I. Bemanding i forhold til opgavekompleks, Power-points. Ledelsessekretariatet, 12

Oct.

FBE, 2008. Analyse - De første 5 udbud af FM. 30 Oct.

FBE, 2008. Smlg. gennemførte udbud. (Excel spreadsheet), 30 Oct.

FBE, 2008. Beslutningsoplæg vedr. Udbudsstrategi for etablissementsdriften. 14 Dec.

Finansministeriet, 1991. Udlicitering af offentlige drifts- og anlægsopgaver. Bet. nr. 1227, Oct. 
Finansministeriet, 1996. Redegørelse til Finansudvalget vedrørende ministeriernes udbud og udlicitering i 1995. 7 Oct.

Finansministeriet, 2005. Budgetredegørelse 2005. June.

Forsvarsministeriet, 2007a. Styringsdokument 2007 mellem Forsvarsministeriet og

Forsvarskommandoen. 28 Feb.

Forsvarsministeriet, 2007b. Forsvarsministeriets koncernledelse. Secretariatet. 19 June.

Forsvarskommandoen 2000. Vision 2010.

Forsvarskommandoen, 2002a. Udlicitering af Dragonkasernen, Holstebro, Rapport vedrørende pilotprojekt Dragonkasernen, Holstebro (PG-OUTS report). 23 May.

Forsvarskommandoen, 2002b. Udlicitering af Dragonkasernen, Holstebro, Rapport vedrørende pilotprojekt Dragonkasernen, Holstebro (PG-OUTS report). 15 July.

Forsvarskommandoen, 2008. Forståelsespapir udarbejdet i rammen af SKS/FBE uformelle arbejdsgruppe vedr. Handlingsplan for etablissementsdriften afledt af McKinsey Review. 16 Nov. Lauth, M. 2009. Forsvaret spilder 120 million kroner. Fagbladet 3F. 12 Feb. Available at: https://fagbladet3f.dk/nyheder/fagligt/b89ea59999b04948ad83190e19b06d41-20090211-forsvaretspilder-120-millioner-kroner (Accessed 26.04.18).

McKinsey, 2008. Review af forsvarets bygnings-og etablissementstjeneste, 3 Nov. 142 pages. McKinsey, 2009, Review af forsvarets bygnings-og etablissementstjeneste, 2 Feb. 49 pages. OECD, 2005. Economic surveys, Denmark. Vol 1 March.

Udliciteringsrådet, Finansministeriet, 2000. Ministeriernes anvendelse af udbud og udlicitering. 2 Feb.

\section{Secondary sources}

Ahrens, T., Ferry, L. and Khalifa, R. 2017. Governmentality's dynamic of forces: The role of calculative practices in attacking the programme of local government funding cuts. Working paper presented at the $10^{\text {th }}$ Workshop on Management Accounting as Social and Organizational practice, Windsor, April.

Akrich, M., Callon, M. \& Latour, B. 1988. The key to success in innovation Part II: The art of choosing good spokespersons, Int. Jour. of Inn. Manage. 6(2), 207-225.

Baxter, J., Carlsson-Wall, M., Chua, W.F. and Kraus, K. (2018). Accounting and passionate interests: The case of a Swedish football club, Account. Organ. and Soc. (forthcoming).

Boedker, C. and Chua, W.F. 2013. Accounting as an affective technology: A study of circulation, agency and entrancement Account. Organ. and Soc. 38, 245-267.

Boltanski, L. and Chiapello, E. 2005. The new spirit of capitalism. London: Verso.

Bourmistrov, A. and Kaarbøe, K. 2013. From comfort to stretch zones: A field study of two multinational companies applying "beyond budgeting” ideas. Manage. Account. Res. 24, 196-211. 
Briers, M. and Chua, W. F. 2001. The role of actor-networks and boundary objects in management accounting change: a field study of an implementation of activity-based costing, Account. Organ. and Soc. 26, 237-269.

Burchell, S., Clubb, C., Hopwood, A., Hughes, A. and Nahapiet, J. 1980. The roles of accounting in organizations and society. Account. Organ. and Soc. 5, 5-27.

Callon, M. 1986. Some elements of a sociology of translation: domestication of the scallops and fishermen of St. Brieuc Bay, in Law, J., (Ed.), Power, Action and Belief: a New Sociology of Knowledge? (pp. 196-233). Routledge, London.

Callon, M. 1987. Society in the making: The study of technology as a tool for sociological analysis. In W. E. Bijker, T. P. Hughes and T. J. Pinch. The social construction of technological systemNew directions in the sociology and history of technology. (pp. 83-103). The MIT Press.

Callon, M. 1991. Techno-economic networks and irreversibility. In J. Law (Ed.), A sociology of Monsters. Essays on power, technology and domination. Routledge.

Callon, M. 1998. An essay on framing and overflowing: economic externalities revisited by sociology, in M. Callon (Ed.), The Laws of the Markets, pp. 244-69.

Callon, M. 2007. What Does It Mean to Say That Economics Is Performative? In D.MacKenzie, F. Muniesa, \& L. Siu (Eds.), Do Economics Make Markets? (pp. 311-357). New Jersey, United States: Princeton University Press.

Callon, M. and Latour, B. 1981. Unscrewing the big Leviathan: How actors macro-structure reality and how sociologists help them to do so. In K. Knorr-Cetina and A. V. Cicourel, Advances in social theory and methodology - towards an integration of micro- and macro-sociologies (pp. 277-303). Boston: Routledge \& Kegan Paul. 
Chenhall, R., Hall, M. and Smith, D. 2014. The expressive role of performance measurement systems: A field study of a mental health development project. Account., Organ. and Soc. doi:10.1016/j.aos.2014.11.002

Christner, C. H. and Strömsten, T. 2015. Scientists, venture capitalists and the stock exchange: The mediating role of accounting in product innovation. Manage. Account. Res. 28, 50-67.

Dai, N.T., Free, C. and Gendron, Y. 2018. Interview-based research in accounting 2000-2014: Informal norms, translation and vibrancy, Manage. Account. Res. In press.

Earl, J. 1978. Prototype systems for accounting, information and control, Account. Organ. And Soc. $3,161-170$.

Foucault, M. 1977. Discipline and Punish: The Birth of the Prison. New York: Pantheon Books. Hammond, T., \& Sikka, P. 1996. Radicalizing accounting history: The potential of oral history. Account., Aud. \& Account. J., 9(3), 79-97.

Golden-Biddle, K. and Locke, K. 1993. Appealing work: An investigation of how ethnographic texts convince. Organ. Sci. 4(4), 595-616.

Graham Harman, G. 2009. Prince of Networks: Bruno Latour and Metaphysics. Melbourne: repress.

Hughes, T. P. 1987. The evolution of large technological systems. In W. E. Bijker, T. P. Hughes and T. J. Pinch, (Eds.). The social construction of technological system - New directions in the sociology and history of technology. (pp. 51-82). The MIT Press.

Jeacle, I. 2003. Accounting and the construction of the standard body. Account. Organ. and Soc. 28, $357-377$.

Jeacle, I. 2017. The popular pursuit of DIY: Exploring the role of calculative technologies in an actor network. Manage. Account. Res. 35, 99-109. 
Justesen, L. and Mouritsen, J. 2011. Effects of actor-network theory in accounting research, Account., Aud. \& Account. Jour. 24, 161-193.

Jordan, S., Jørgensen, L. and Mitterhofer, H. 2013. Performing risk and the project: Risk maps as mediating instruments. Manage. Account. Res. 24, 156-174.

Kaplan, R., 1986. The role for empirical research in management accounting. Account. Organ. and Soc. $11,429-452$.

Latour, B. 1987. Science in Action, Cambridge, Mass: Harvard University Press.

Latour, B. 1988. The Pasteurization of France, Harvard University Press, London, England.

Latour, B. 1993. We have never been modern. Harvard University Press.

Latour, B. 1994. On technical mediation - philosophy, sociology, genealogy. Comm. Knowl. 3 (2), 29-64.

Latour, B. 2002. Morality and technology—the end of the means. Theo., Cult. \& Soc. $19(5 / 6), 247-60$.

Latour, B. 2005. Reassembling the Social - An Introduction to Actor-Network-Theory. Oxford: Oxford University Press.

Law, J. 1987. Technology and heterogeneous engineering: the case of Portugese expansion. In W.

E. Bijker, T. P. Hughes and T. J. Pinch. The social construction of technological system - New directions in the sociology and history of technology. (pp. 111-134). The MIT Press.

Lincoln, Y. and., Guba, E. 1985. Naturalistic Inquiry. Sage Publications, Newbury Park, CA.

Lowe, A. 2000. The construction of a network at health Waikato - the "towards clinical budgeting project", Account. Account. and Account. Jour. 13, 84-114.

Lukka, K. and Modell, S. 2010. Validation in interpretive management accounting research. Account. Organ. and Soc. 35, 462-477.

Miller, P. and O'Leary, T. 2002. Rethinking the factory: Caterpillar Inc., Cult. Valu., 6, 91-117. 
Miller and O’Leary 2007. Mediating instruments and making markets: capital budgeting, science and the economy. Account. Organ. and Soc. 32 (7/8), 701-734.

Miller, P. and Power, M. 2013. Accounting, organizing, and economizing: connecting accounting research and organization theory. Acad. of Manage. Annals, 7 (1), 557-605.

Miller, P. and Rose, N. 1990. Governing economic life. Econ. and Soc., 19, 1-31.

Miller, P. and N.S. Rose, N. 2008. Governing the Present: Administering Economic, Social and Personal Life. Cambridge: Polity Press.

Morrison, M. and Morgan, M. 1999. Models as mediating instruments. In M. Morgan \& M.

Morrison (Eds.), Models as mediators: Perspectives on Natural and Social Science. Cambridge:

Cambridge University Press.

Napier, C. 2006. Accounts of change: 30 years of historical accounting research, Account. Organ. and Soc. 31, 445-507.

Preston, A., Cooper, D. J., Coombs, R. W. 1992. Fabricating Budgets: A study of the production of management budgeting in the national health service. Account. Organ. and Soc. 17 (6), 561-593. Revellino, S. and Mouritsen, J. 2009. The multiplicity of controls and the making of innovation, Euro. Account. Rev. 18 (2), 341-369.

Revellino, S. and Mouritsen, J. 2015. Accounting as an engine: The performativity of calculative practices and the dynamics of innovation. Manage. Account. Res. 28, 31-49.

Robson, K. 1992. Accounting numbers as "inscription": Action at a distance and the development of Accounting, Account. Organ. and Soc. 17, 685-708.

Robson, K., Humphrey, C., Khalifa, R. and Jones, J. 2007. Transforming audit technologies: Business risk audit methodologies and the audit field, Account. Organ. and Soc. 32 (4-5), 409-438. Rowe, C., Shields, M. and Birnberg, J. 2012. Hardening soft accounting information: Games for planning organizational change. Account. Organ. and Soc. 37, 260-279 
Skærbæk, P. 2009. Public sector auditor identities in making efficiency auditable: The National Audit Office of Denmark as independent auditor and modernizer. Account. Organ. and Soc. 34, 971-987.

Skærbæk, P. and Tryggestad, K. 2010. The role of accounting devices in performing corporate strategy. Account. Organ. and Soc. 35, 108-124.

Vaivio, J. 1999. Examining “The Quantified Customer". Account. Organ. and Soc. 24, 689-715. 


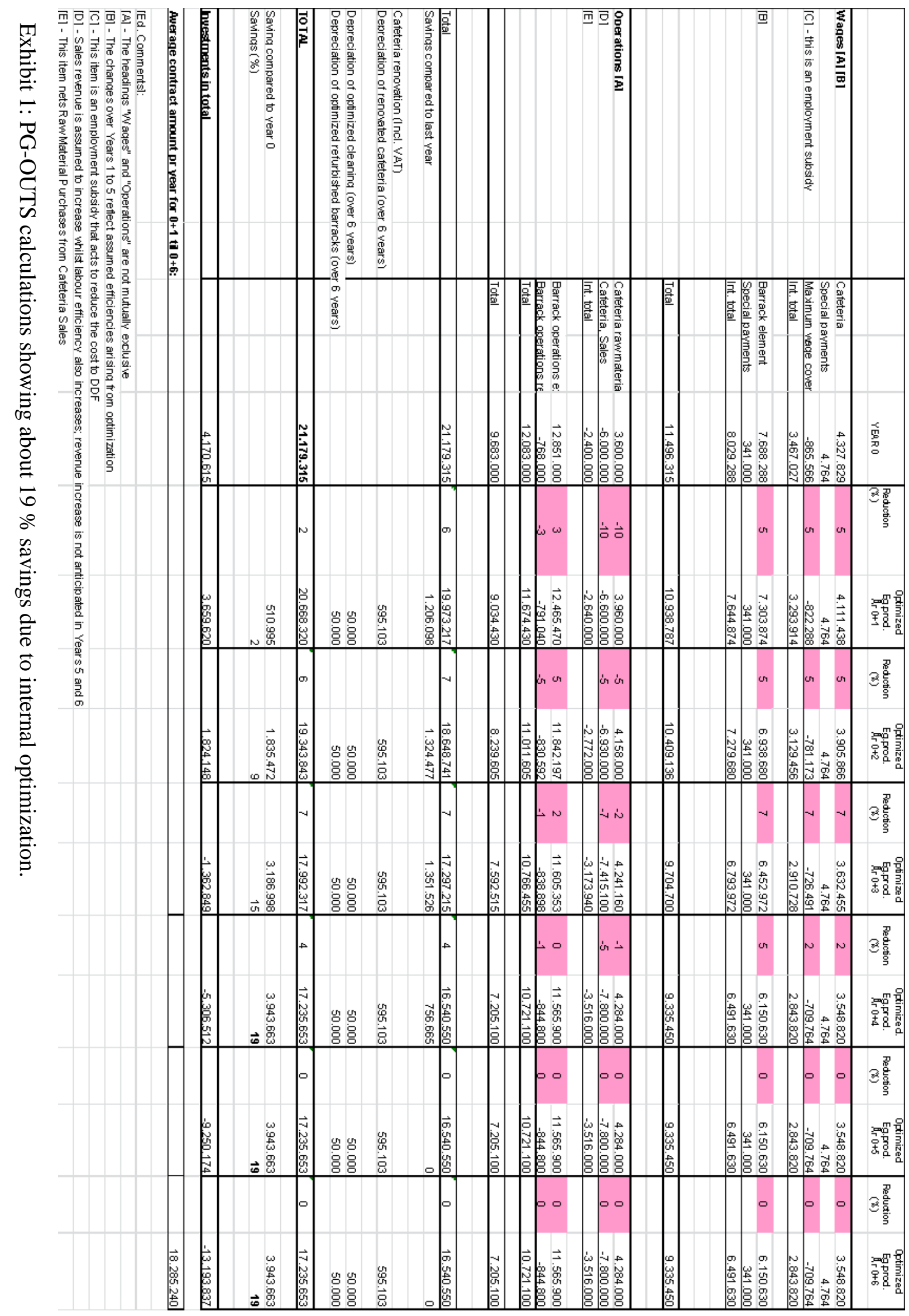




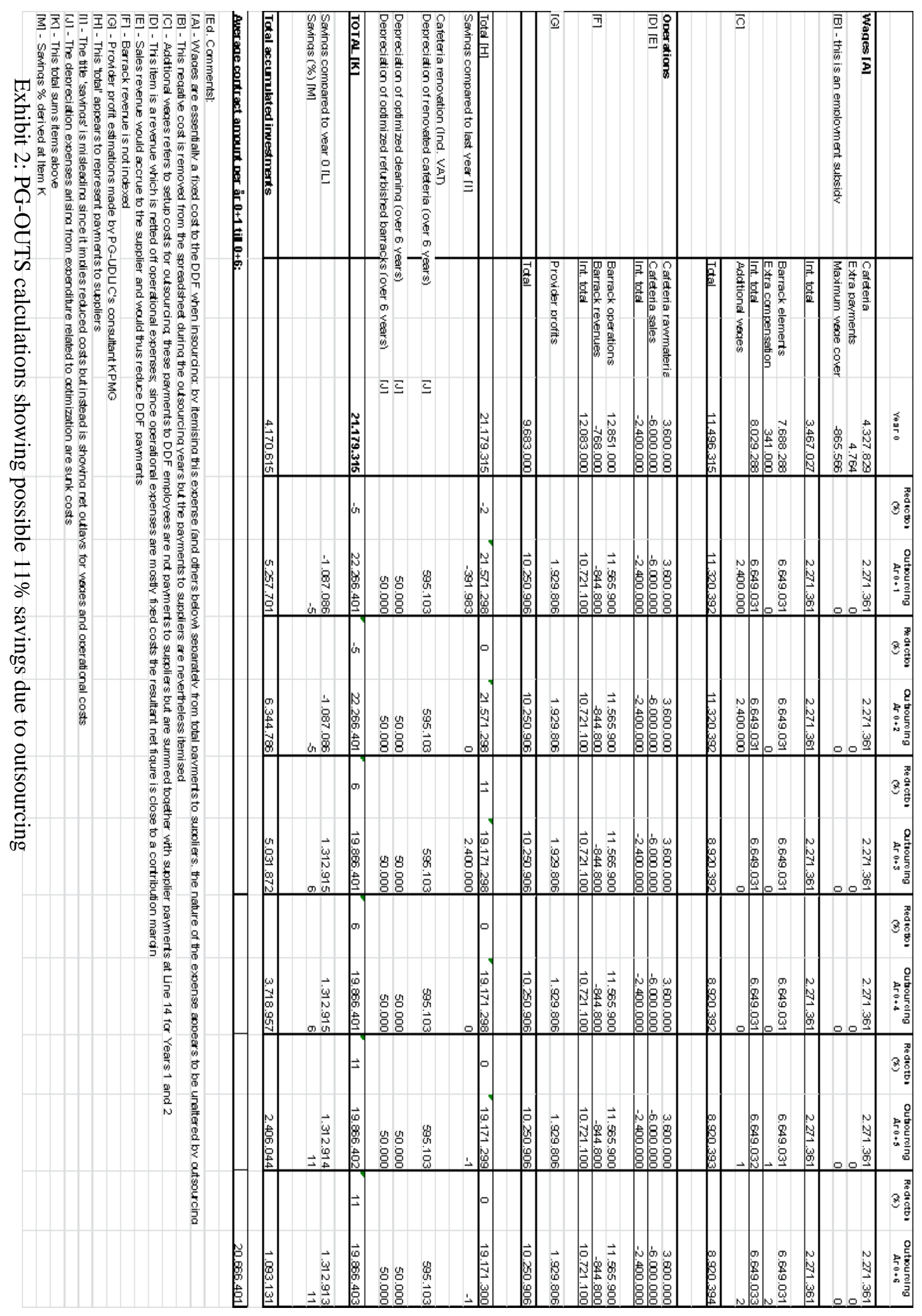

